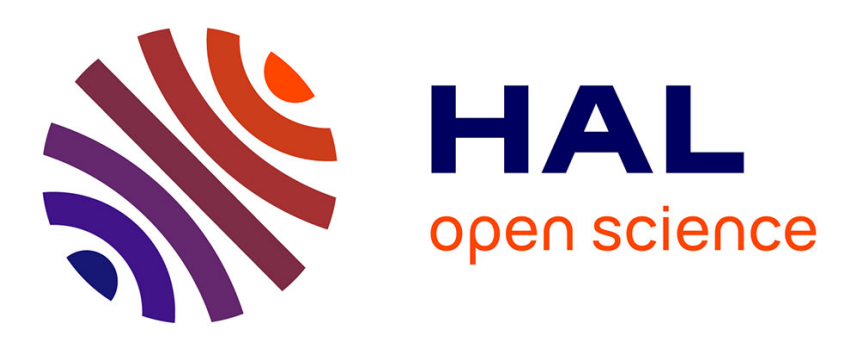

\title{
Spatial variability of trace elements in allotment gardens of four European cities: assessments at city, garden, and plot scale
}

Béatrice Bechet, Sophie Joimel, Liliane Jean-Soro, Andrew Hursthouse, Alaba Agboola, Teresa E. Leitão, Hugo Costa, Maria Do Rosário Cameira, Cécile Le Guern, Christophe Schwartz, et al.

\section{To cite this version:}

Béatrice Bechet, Sophie Joimel, Liliane Jean-Soro, Andrew Hursthouse, Alaba Agboola, et al.. Spatial variability of trace elements in allotment gardens of four European cities: assessments at city, garden, and plot scale. Journal of Soils and Sediments, 2018, 18 (2), pp.391-406. 10.1007/s11368-016-1515-1 . hal-01655399

\section{HAL Id: hal-01655399 https://hal.science/hal-01655399}

Submitted on 26 May 2020

HAL is a multi-disciplinary open access archive for the deposit and dissemination of scientific research documents, whether they are published or not. The documents may come from teaching and research institutions in France or abroad, or from public or private research centers.
L'archive ouverte pluridisciplinaire HAL, est destinée au dépôt et à la diffusion de documents scientifiques de niveau recherche, publiés ou non, émanant des établissements d'enseignement et de recherche français ou étrangers, des laboratoires publics ou privés. 
Spatial variability of trace elements in allotment gardens of four European cities: assessments at city, garden, and plot scale

Béatrice Bechet, Sophie Joimel, Liliane Jean-Soro, Andrew Hursthouse, Alaba Agboola, Teresa E. Leitão, Hugo Costa, Maria do Rosário Cameira, et al.

Journal of Soils and Sediments

ISSN 1439-0108

Volume 18

Number 2

J Soils Sediments (2018) 18:391-406 DOI 10.1007/s11368-016-1515-1

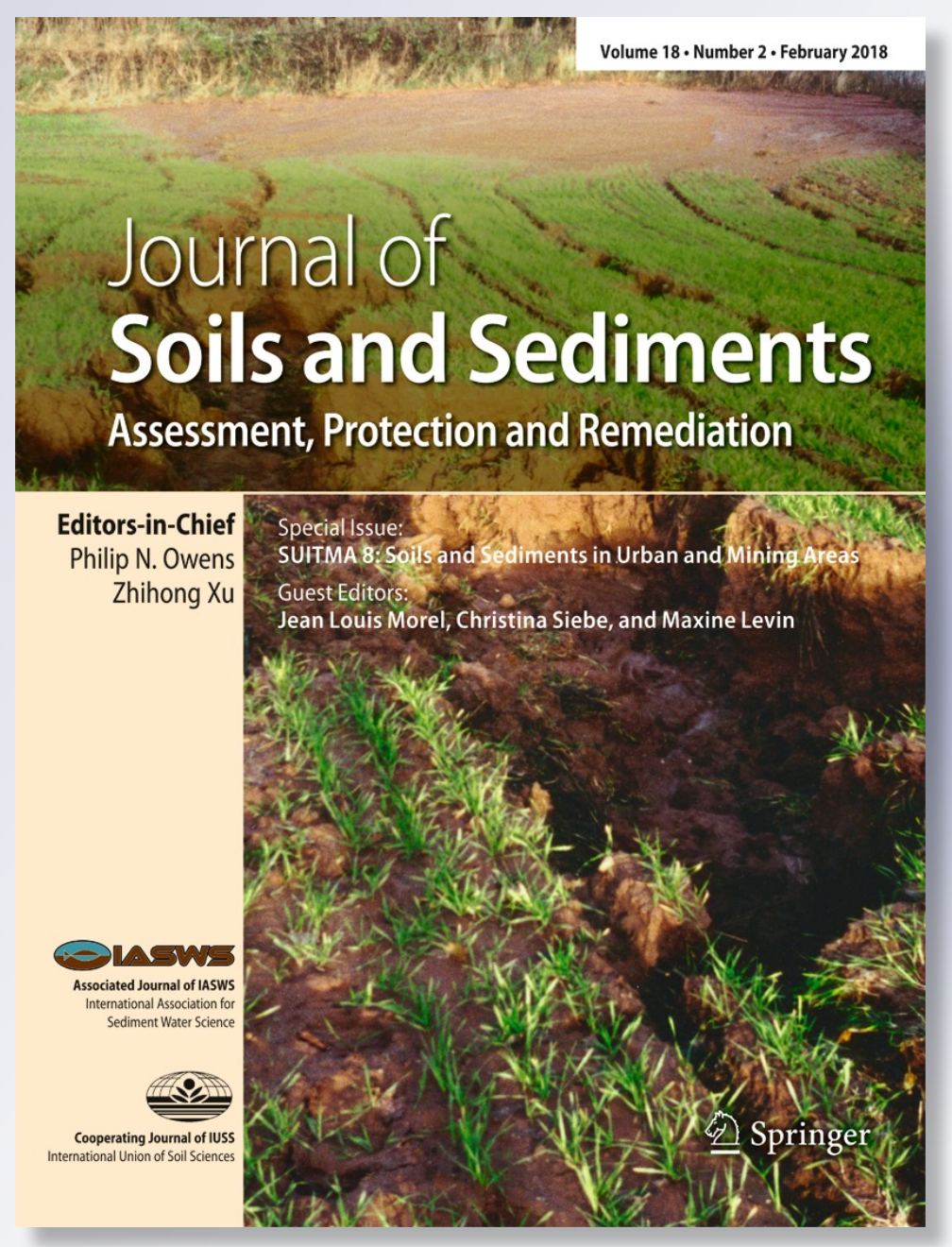

望 Springer 
Your article is protected by copyright and all rights are held exclusively by SpringerVerlag Berlin Heidelberg. This e-offprint is for personal use only and shall not be selfarchived in electronic repositories. If you wish to self-archive your article, please use the accepted manuscript version for posting on your own website. You may further deposit the accepted manuscript version in any repository, provided it is only made publicly available 12 months after official publication or later and provided acknowledgement is given to the original source of publication and a link is inserted to the published article on Springer's website. The link must be accompanied by the following text: "The final publication is available at link.springer.com". 


\title{
Spatial variability of trace elements in allotment gardens of four European cities: assessments at city, garden, and plot scale
}

\author{
Béatrice Bechet $^{1,2} \cdot$ Sophie Joimel ${ }^{3,4}$ - Liliane Jean-Soro ${ }^{1,2}$ • Andrew Hursthouse ${ }^{5}$. \\ Alaba Agboola ${ }^{5}$. Teresa E. Leitão ${ }^{6} \cdot \mathrm{Hugo}_{\text {Costa }}{ }^{7} \cdot$ Maria do Rosário Cameira $^{8}$. \\ Cécile Le Guern $^{2,9} \cdot$ Christophe Schwartz $^{4}$. Thierry Lebeau ${ }^{2,10}$
}

Received: 30 January 2016 / Accepted: 19 July 2016 /Published online: 24 August 2016

(C) Springer-Verlag Berlin Heidelberg 2016

\begin{abstract}
Purpose Urban allotment gardens (UAGs) are expanding worldwide, especially in large cities. Environmental pressures (direct and diffuse pollution, gardener practice, geogenic contamination) often result in the accumulation of potentially harmful trace elements in garden soils. The objectives of this study were to assess the spatial variability of trace element distribution in UAGs from city, garden, and plot scale in four European cities; to provide a baseline understanding and identify abnormal values under environmental pressures; and to evaluate the potential of portable X-ray fluorescence screening as a useful tool in soil management.

Materials and methods The four cities (Ayr and Greenock (Scotland), Lisbon (Portugal), Nantes (France)) provided a
\end{abstract}

Responsible editor: Jean Louis Morel

Electronic supplementary material The online version of this article (doi:10.1007/s11368-016-1515-1) contains supplementary material, which is available to authorized users.

\section{Béatrice Bechet}

beatrice.bechet@ifsttar.fr

1 Water and Environment Laboratory, French Institute of Science and Technology for Transport, Development and Networks, CS4, Route de Bouaye, 44344 Bouguenais Cedex, France

2 Institut de Recherche en Sciences et Techniques de la Ville FR CNRS 2488, Ecole Centrale de Nantes, BP 92101, 1 rue de la Noë, 44321 Nantes, France

3 UMR Ecosys (Ecologie Fonctionnelle et Ecotoxicologie des Agroécosystèmes), AgroParisTech, Campus AgroParisTech Grignon Bâtiment EGER, 78850 Thiverval Grignon, France

4 Laboratoire Sols et Environnement UMR 1120, Université de Lorraine INRA, TSA 40602, 2 Avenue de la forêt de Haye, Vandoeuvre-lès-Nancy Cedex 54518, France wide range of environmental pressures on soils. The locations of the 14 allotment gardens were identified in consultation with the local municipality in each city to reflect various land uses or according to previous evaluation of soil quality. Soil sampling was carried out in 66 plots in total, from which 3 datasets were produced: (i) basic soil properties and trace element concentrations from a composite sample of topsoil for each plot (trace elements quantified by inductively coupled plasma-optical emission spectrometry/mass spectrometry (ICP-OES/MS) or using in-lab portable X-ray fluorescence (PXRF); (ii) in situ PXRF measurement on composite samples (263 plots in Nantes); and (iii) composite samples from 32 small areas within 4 plots in one garden of Nantes.

5 School of Science and Sport, University of the West of Scotland, Paisley Campus, Paisley PA1 2BE, UK

6 National Laboratory for Civil Engineering, Av. do Brasil, 101 1700-066 Lisbon, Portugal

7 Cooperating with National Laboratory for Civil Engineering under COST 1201, Av. do Brasil, 101 1700-066 Lisbon, Portugal

8 Instituto Superior de Agronomia, LEAF, University of Lisbon, Tapada da Ajuda, 1349-017 Lisbon, Portugal

9 Regional Geological Survey Pays de la Loire, Bureau de Recherches Géologiques et Minières, 1 rue des Saumonières, 44000 Nantes, France

10 UMR LPG-Nantes 6112 CNRS, Université de Nantes, BP 92208, 2 rue de la Houssinière, 44322 Nantes Cedex 3, France 
Results and discussion The results were analyzed to assess the spatial variability of soil properties. At city and garden scale, the variability observed for basic soil properties and major elements is dominated by local geology/parent material $(\mathrm{pH}$, $\left.\mathrm{CaCO}_{3}, \mathrm{Fe}\right)$ and gardening practice $\left(\mathrm{OM}, \mathrm{CaCO}_{3}\right)$, which vary between each country. The range of trace element concentrations is similar between each city except for Greenock. Extreme values are observed for $\mathrm{Cu}, \mathrm{Pb}$, and $\mathrm{Zn}$ reflecting human disruption. In most situations, the trace element contamination was explained through the historical and environmental situations of the site. The PXRF screening method proved useful in providing detailed mapping for hot spot detection or delineation, providing support for soil management at plot and garden scale.

Conclusions As anticipated, basic soil properties appear to be controlled by the parent material. At plot and garden scale, the trace element variability shows the influence of land use history and background and strong inputs from external factors (e.g., by industrial activity or traffic emission). The PXRF screening method appears to be an efficient solution for soil management as it can be used to discriminate zones which may require restriction on cultivation.

Keywords PXRF · Soil management - Spatial variability · Trace elements $\cdot$ Urban allotment garden soil

\section{Introduction}

Urban allotment gardens (UAGs) are expanding worldwide, especially in industrialized countries (Draper and Freedman 2010; Guitart et al. 2012). However, gardens in the urban environment are often subject to environmental pressures, mainly as a result of pollution from urban and industrial activities as well as through gardener's practices. Cultivated urban soils can be contaminated as they are often located on previously urbanized sites and suffer from impact by human activities, such as industrial emissions or road traffic (Leitão 2007; Rodrigues et al. 2009; Béchet et al. 2009; Li et al. 2013). Consequently, urban soils can accumulate significant quantities of harmful substances (Papritz and Reichard 2009; El Hamiani et al. 2010; Orecchio 2010), such as (i) trace metals or metalloids, e.g., lead, arsenic, copper, mercury, and zinc (KabataPendias 2001; Hursthouse et al. 2004; Schwartz et al. 2013; Joimel et al. 2016), and (ii) polycyclic aromatic hydrocarbons (PAHs) and other persistent organic pollutants (Morillo et al. 2007; Cachada et al. 2009). In some cases, significant quantities of potentially harmful trace elements may also have a geogenic origin from metalliferous mineralization, resulting in abnormally high concentrations in soils (Ander et al. 2013; Karim et al. 2014; Jean-Soro et al. 2015). Recent studies on garden soils highlight the range of origins of contamination and the cumulative impact of human activities on urban garden soil quality (Szolnoki et al. 2013; Mitchell et al. 2014). Potential risks to human health can derive from exposure to significant quantities of harmful substances either by consumption of contaminated vegetables, breathing dust after resuspension, or by direct contact with soil (Nabulo et al. 2010; Singh et al. 2012; Douay et al. 2013; McBride et al. 2014). It was established that direct soil ingestion and inhalation as well as dermal contact with soil particles must be considered as pathways of human exposition, especially for children, although the primary route was shown to be the diet (Hough et al. 2004; Bian et al. 2015; Liu et al. 2013). To evaluate risks, the spatial variability of heavy metal distribution between and within plots needs to be assessed (Schwarz et al. 2012; Szolnoki et al. 2013). The variability of exposure in the gardens and impact of external sources (transport infrastructures, constructions processes) adds further complexity.

The variability of potentially toxic elements in garden soils is likely to be high, considering the range of sources and individual gardener behavior on plots. This may affect the availability for uptake or contamination of garden produce and consequently exposure. It is important for recommendations for management of the activities to be able to define the likely magnitude of this variability and consequence for exposure assessment. A similar question was addressed by Zahran et al. (2013), focusing on urban soil lead pollution at city scale and child health. The location of sampling zones was shown to be a main parameter to link soil quality and lead in blood. The authors recommended actions in urban planning to reduce exposure. Few studies have reported the relation between the high variability of soil and vegetable contamination between and within sites (Nabulo et al. 2010; Mc Bride et al. 2014) and the consequences for decision-making procedures to minimize exposure. Bugdalski et al. (2014) examined small-scale spatial variability of soil lead within a $15 \times 30$-m urban garden plot. They concluded that the spatial variability at the scale of $5 \mathrm{~m}$ or less coupled with the presence of hot spots requires clearly defined sampling objectives and strategies. For Clarke et al. (2015), the knowledge of soil geochemistry and metal bioavailability could allow incorporation of contamination patterns into urban planning, particularly if early assessment highlights specific locations where risk may be significant.

To provide further evaluation of short-scale soil variability on plot-level management, this study addresses a comparative assessment to evaluate variability at city, garden, and plot scale. It supports the issue of relating the low or high variability to environmental factors such as natural or anthropogenic inputs. In supporting the contamination of the food chain in UAGs, are methods available which can support high- 
resolution assessment of contamination to maximize knowledge on a plot scale and maintain most productive use of the sites?

We offer insights supported by case studies from four European cities: (i) the need for greater understanding of the heterogeneity for trace element sources, including geogenic signatures, atmospheric deposition, and inputs; (ii) the need to take into consideration local environmental histories (including land use) in any UAG study and consequences for further studies; and (iii) the potential for portable X-ray fluorescence (PXRF) multi-element spectrum analyzer as a useful method for detection of spatial heterogeneity of trace element distribution and delineation of zones of concern at garden and plot scale, supporting improvement in public health.

Investigation of the contamination of UAG soils was carried out in four European cities: Greenock and Ayr (Scotland), Lisbon (Portugal), and Nantes (France). Soils were sampled to characterize some basic physical properties and chemical properties (major elements, contamination by trace elements). The results were analyzed to evaluate the contamination of the UAG soils at city scale, taking into account the properties of topsoil, the geochemical background, and the anthropogenic activities (vs. geogenic anomalies). The aim is not to merge all the four case studies together into one statistical population but to use the case studies to provide insight to a European-wide practice. The heterogeneity of the soil contamination within each UAG was investigated to provide supporting information for the most appropriate management methods for soil use in the case of excessive contamination. In the city of Nantes, the relevance of in situ measurements by PXRF multi-element spectrum analyzer was addressed as a technical means to help in decision-making.

\section{Materials and methods}

\subsection{Study area in the four European cities}

The four cities selected provided a wide range in pedoclimatic conditions, geology, density of population, and likely sources of pollution. The locations of UAGs were chosen in consultation with the local municipality in each city to reflect various land uses or according to previous evaluation of soil quality. Both local councils/authorities and associations ensure the governance of the gardens. The council is responsible for the creation and maintenance of the gardens; the association within each garden entrusts the everyday management. Crops produced vary but include vegetable production for personal consumption, with additional fruits and flowers. The total surface area of UAGs represents less than $0.5 \%$ of total surface area of each city.

\subsubsection{Ayr and Greenock (Scotland)}

Greenock is a small town in Inverclyde with 44,248 people (Fig. 1a). The annual rainfall is $1494 \mathrm{~mm}$, and the former activities in the town are shipbuilding, manufacturing, and shipping (Fig. 1a). It is part of the extensively industrialized region of the Clyde valley, with historic and extensive industrial activity. Ayr is a small town in Ayrshire with 46,050 people (Fig. 1a). The average annual rainfall is $902.3 \mathrm{~mm}$; the town is characterized by historic manufacturing of textiles such as carpets and lining until the factories were closed down in the 1970s. It is surrounded by farmland. Both towns have oceanic and mountain temperate climate with volcanic and sedimentary bedrocks, $\mathrm{Fe}$ and $\mathrm{Zn}$ as background enrichment and low acidic pH (Fig. 1a). The background soils have acidic and organic-rich surface layers. In Ayr soil, parent materials are fluvial clays, silts and gravels, and marine or estuarine sands. In Greenock, parent materials are a mix of basalts and glacial till. Garden selection in these two towns was based on accessibility and on contamination potential previously detected in at least one case. The characteristics of studied UAGs in Greenock and Ayr are summarized in Table 1.

\subsubsection{Lisbon (Portugal)}

Lisbon is the capital and the largest city of Portugal, with a population of 552,700 within its administrative limits, in an area of $100 \mathrm{~km}^{2}$ (5527 inhabitants per sq. km). Its urban area extends beyond the city's administrative limits with a population of around 2.7 million people. Lisbon lies in the western Iberian Peninsula along the Atlantic coast and the Tagus River. It enjoys a subtropicalMediterranean climate with an average annual rainfall of $775 \mathrm{~mm}$. The study sites were located at six places around the city (Fig. 1b). The selection of gardens was based on their location in relation to different urban pressures (roads, airport, etc.) and different soil parent materials. None of the sites had previously been subject to industrial activity. The main characteristics of the studied UAGs in Lisbon are presented in Table 1.

The geological formations, in the area of Lisbon, are described on the local 1:10,000 geological map of Lisbon (Moitinho de Almeida 1986) (Fig. 1b). In the allotment gardens of Chelas, Laboratório Nacional de Engenharia Civil (LNEC), and Centro Hospitalar Psiquiátrico de Lisboa (CHPL), the geological formations include Lisbon Miocene formations (sand, clay, and limestone) and the alluvial nature coverage of deposits associated with the valleys. The Miocene age formations correspond to a set of sequences that alternate between depositional units marine, brackish, and continental (Pais et al. 2006). The geological formations of Granja and 
Granja Nova include volcanic nature rocks (south) and sedimentary rocks from the Miocene and alluvial nature coverage deposits. Finally, Circular Regional Interior de Lisboa (CRIL) is located in the volcanic complex of Lisbon, being composed of volcanic soils.

\subsubsection{Nantes (France)}

Nantes is the largest city of the Pays de Loire in north-western France. It is located $40 \mathrm{~km}$ east of the Atlantic Sea coast. Nantes has about 300,000 inhabitants in an area of $65 \mathrm{~km}^{2}$ (4100 inhabitants per sq. km) and enjoys an oceanic climate ( $820 \mathrm{~mm}$ rainfall/year). The study sites were located at six places around the city (Fig.1c). Inside the urban area, allotment gardens were selected according to land use typology (residential, industrial, semi-natural; Joimel et al. 2016). The characteristics of the studied UAGs are presented in Table 1. Depending on the extent of soil characterization, a varied number of plots (4 to 95) were sampled per garden.

The geological formations, in the area of Nantes, described on the local 1:50,000 geological map of Nantes (Ters et al. 1969; Béchennec 2007) are (Fig. 1c) (i) micaschists and gneiss with more or less mineralized veins (e.g., pegmatite, aplite, quartz...) and granite as parent material, (ii) superficial deposits such as alteration materials and sandy formation (marine transgression), and (iii) Quaternary eolian deposits (mainly silt). Lead is often found in association with arsenic within alterites of micaschistes in the area.

\subsection{Soil sampling and methods}

Details of sample collection strategy are provided in Table 2. Three soil datasets were produced from this study.

The first set consisted of topsoil samples collected from parallel sampling campaigns in a restricted number of allotments gardens (and the individual plots therein) in the four towns/cities. Various sampling and analyses were conducted in the four cities. But, all samples are taken from the cultivated layer that is digged once or twice a year. In one city (Lisbon), soil replicate samples $(0-5 \mathrm{~cm})$ were collected randomly by hand using a plastic spade. The composite samples were analyzed for metal content by PXRF (laboratory conditions). In the other cities, a standard soil-coring device was used to collect replicate samples $(0-20 \mathrm{~cm})$. The composite samples were then analyzed, using inductively coupled plasma-optical emission spectrometry (ICP-OES) and inductively coupled plasma-mass spectrometry (ICP-MS). The following basic statistics are calculated: mean value, relative standard deviation (\%RSD), minimum value, maximum value, and standard error (SE) (Webster 2001). The trace element concentrations are compared to average concentrations representative of geochemical background from the
Fig. 1 Location of the four cities and of the studied gardens on the local geological map, a Ayr and Greenock (Scotland), b Lisbon (Portugal), and c Nantes (France)

literature (Table 4) or to local specific data on background for Nantes (Sect. 3.3) (Le Guern et al. 2013).

In all cases, the soil samples were prepared according to the ISO 11464 standard. Samples were air-dried at room temperature and crushed to pass through a 2-mm stainless steel sieve. Artifacts such as stones, leaves, glass, or iron/metal artifacts were removed. Some of the samples were characterized using standard methods for the basic soil quality parameters, $\mathrm{pH}$, organic matter, $\mathrm{CaCO}_{3}$, and particle size distribution. Soil samples were digested with aqua regia using hot block at $95^{\circ} \mathrm{C}$ before metal content and major element screening.

The second sample set is based on PXRF measurements of composite samples collected in a large number of plots in some of the allotment gardens of Nantes. The equipment used was a field portable X-ray fluorescence analyzer (Niton XL3t GOLDD). The accuracy of measurements was checked by analysis of $10 \%$ of the samples with a normalized laboratory method (NF X31-147; acid digestion with $\mathrm{HF}$ and $\mathrm{HClO}_{4}$, analysis by ICP-MS; Varian 820-MS). All sampling points were located using a Differential Global Positioning System (DGPS). The spatial distribution of trace element content was mapped using MapInfo 8.5.

The last set resulted from analysis and trace element measurements performed on several spots in a very restricted number of plots in Nantes (Table 2). In the "Jardin des Eglantiers" (Nantes), the variability within plots was investigated on four adjoining plots. The area was subdivided into 32 zones of $6 \mathrm{~m}^{2}$ each. A composite sample consisted of five subsamples recovered at each corner and one at the center of each zone. The $\mathrm{pH}$ value of each composite soil sample was measured according to the NF ISO 10390 (AFNOR 2005) standard. Total soil $\mathrm{Pb}$ was analyzed on each sample using a portable X-ray fluorescence tool (Niton 792), with $10 \%$ of the samples also being analyzed after acid digestion in order to calibrate the device.

\section{Results and discussion}

\subsection{Factors of trace element spatial-scale variability in UAG soils at city scale_ — case of Lisbon and Nantes}

The overall evaluation of UAG soil contamination is often performed at city scale by local authorities. Either composite samples from delimited zones in gardens or randomly collected samples are analyzed (one to five samples per garden). In this study, datasets are available to carry out comparisons between Lisbon and Nantes (Table 2). The objective is to determine to which extent 
a

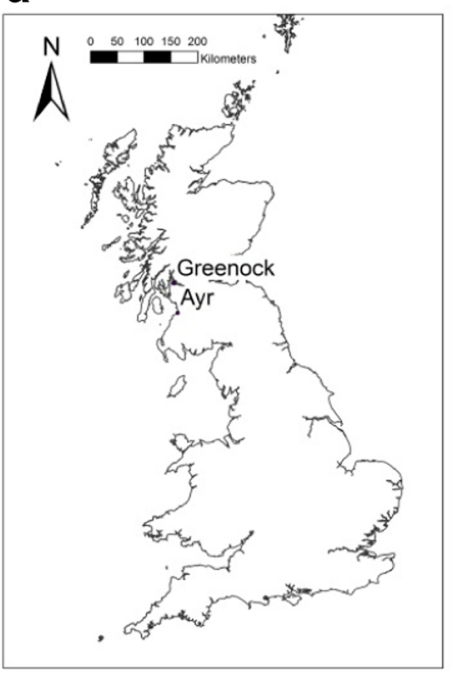

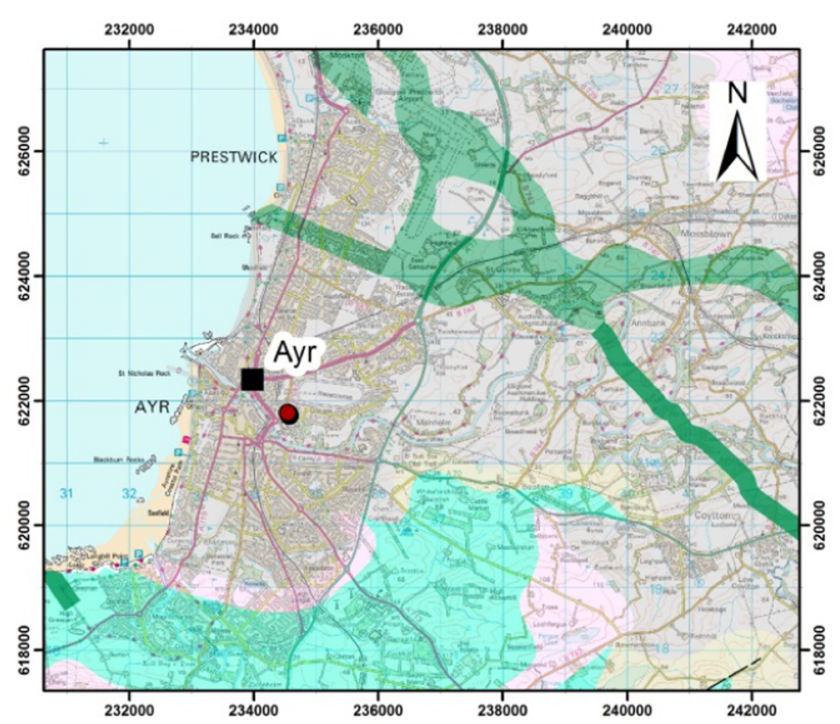

Legend

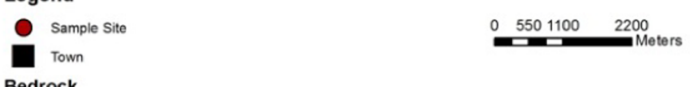

Bedrock

LEX_RCS_I

UNNAMED IGNEOUS INTRUSION, PALAEOGENE - MAFIC IGNEOUS-ROCK

UNNAMED EXTRUSIVE ROCKS, PERMIAN - MAFIC LAVAAND MAFIC TUFF

INVERCLYDE GROUP - SANDSTONE, SILTSTONE AND MUDSTONE

UNNAMED EXTRUSIVE ROCKS, SILURIAN TO DEVONIAN - MAFIC LAVAAND MAFIC TUFF

Ckn-cyoc

Inv-sdsm

Vexsd-latm

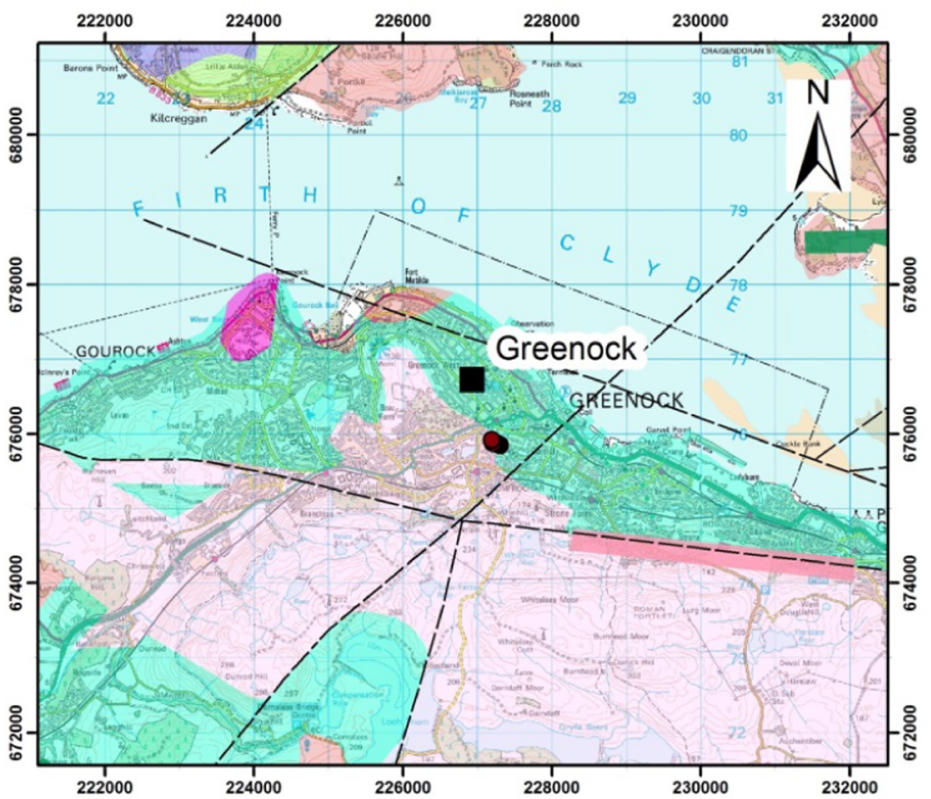

Legend

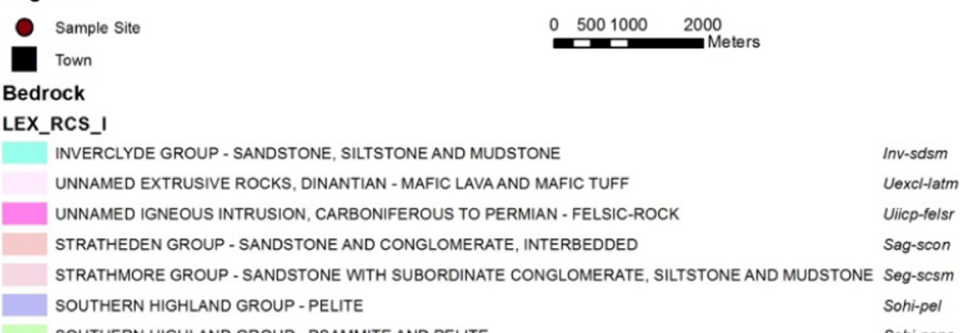

SOUTHERN HIGHLAND GROUP - PSAMMITE AND PELITE SOhi-pspe 
b
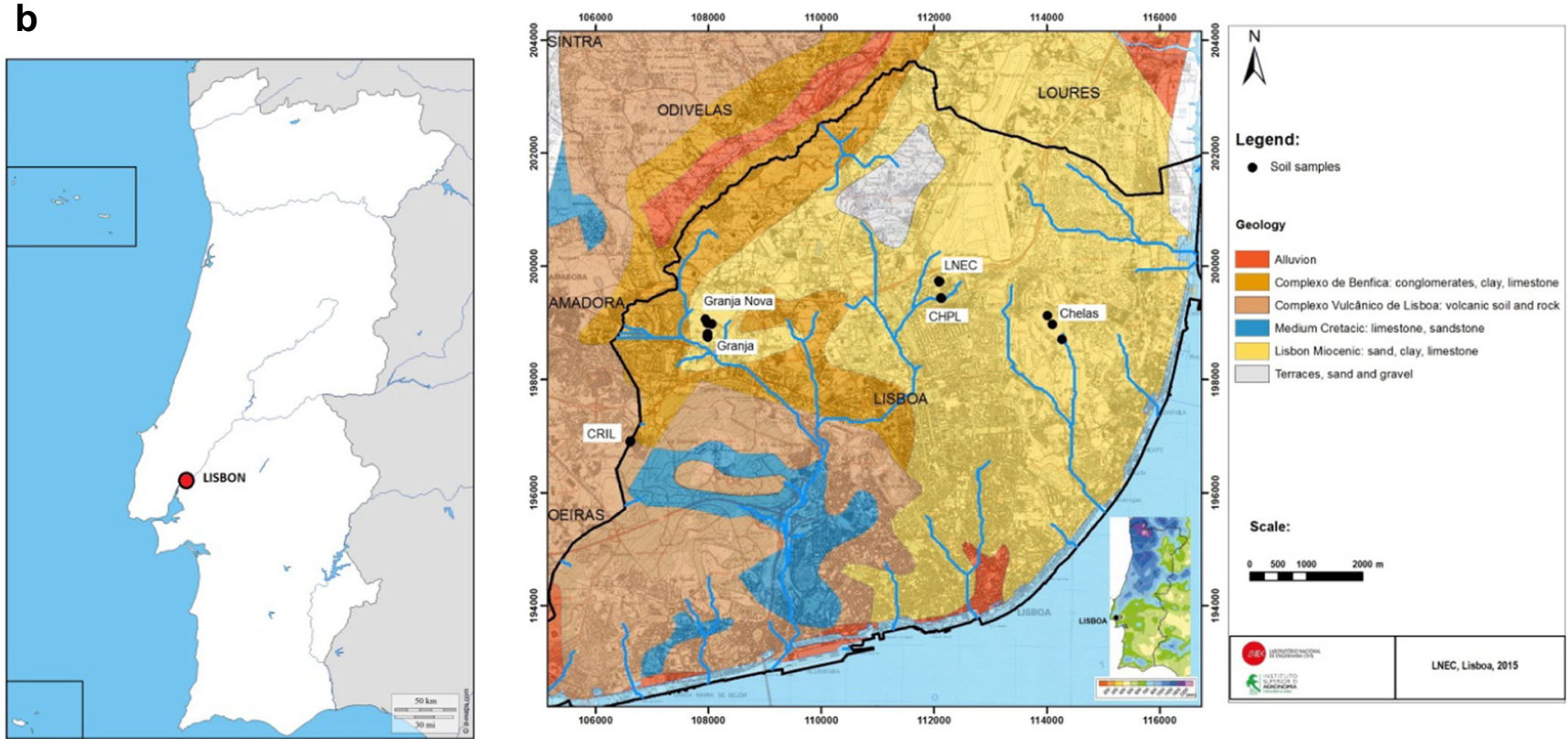

(modified from $\mathbb{C}$ http://d-maps.com)

C

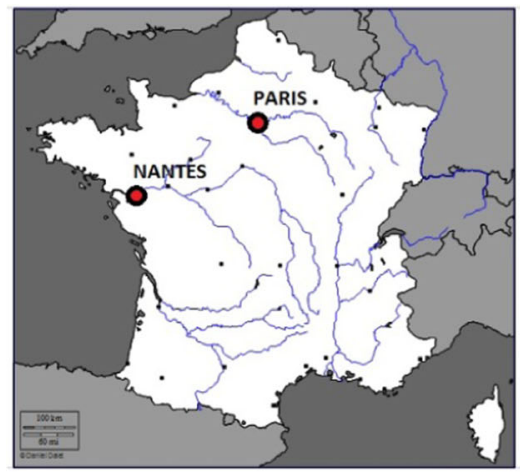

(modified from $(\mathcal{C}$ histgeo.ac-aixmarseille.fr)

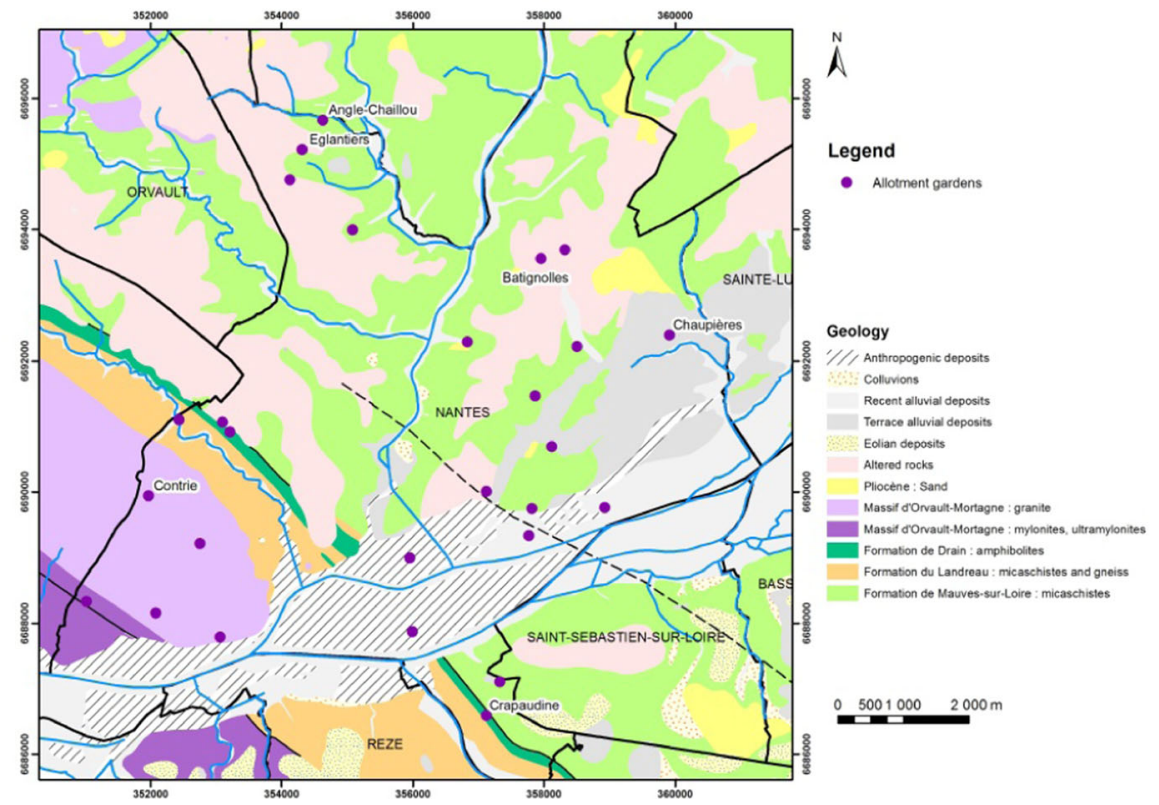

Fig. 1 (continued)

the variability could be explained by environmental factors, focusing essentially on geogenic signatures and anthropogenic activities. Results for trace element concentrations are shown in Fig. 2, and data for basic soil properties and metal content in soils samples are summarized in Tables 3 and 4.

The data may observe that some elements have the same trend: (i) $\mathrm{Pb}, \mathrm{Zn}$, and $\mathrm{Cu}$ - same pattern of concentrations (mean value, high extreme values for $\mathrm{Pb}$ and $\mathrm{Zn}$ and to a less extent for $\mathrm{Cu}$ ) in Lisbon and Nantes, and (ii) $\mathrm{Ni}, \mathrm{Cr}$, and $\mathrm{Cd}-$ different pattern between Lisbon and Nantes (mean concentration or RSD).

Previous studies have largely identified the role of urban built environment, environmental exposures, and native parent material on the urban soil quality and trace element content (Hursthouse et al. 2004; Yesilonis et al. 2008; Rodrigues et al. 2009; Schwarz et al. 2012).

The influence of the native parent material on the garden soils is evaluated against the geological data on city areas and the background geochemistry reference values listed in 
Table 4. In Lisbon, the volcanic rocks are proved to be sources of major metallic elements, such as Fe and Mn (Table 4). Other trace elements such as $\mathrm{Cr}, \mathrm{Ni}$, and $\mathrm{Zn}$ can also derive from the chemical composition of this parent rock. $\mathrm{Ni}$ and $\mathrm{Zn}$ concentrations in the background range of igneous rocks support this hypothesis. By contrast, $\mathrm{Pb}$ mean concentration is clearly above the reference values for igneous and sedimentary rocks. The area of Nantes is characterized by local high levels of $\mathrm{Pb}$ (up to $500 \mathrm{mg} \mathrm{kg}^{-1}$ ) (Le Guern et al. 2013). Among the trace elements, $\mathrm{Pb}$ and $\mathrm{Cd}$ mean concentrations are above the reference values for igneous rocks. $\mathrm{Zn}$ is in the background range of igneous rocks. $\mathrm{Cu}$ and $\mathrm{Cr}$ values for both cities are under the average concentrations for igneous rocks.

Basic soil parameters could also be indicators of potential variability of trace element concentrations. The $\mathrm{pH}$ value, carbonate content, and organic matter may act on the retention of trace elements in garden soils and are either controlled by natural conditions or by inputs in soils by gardeners. The $\mathrm{pH}$ values of Lisbon and Nantes soils are in the range of neutral to alkaline similar to natural soils (6.5-8.5), with a standard deviation about $0.5 \mathrm{u}$ among each city. The range for $\mathrm{pH}$ values in Lisbon is higher than those of Nantes related to local geology. The higher variability of $\mathrm{CaCO}_{3}$ content in Lisbon is attributed to wider range of parent materials, including carbonate containing parent material (sedimentary rocks), considering that amendments could also induce quite large variability between gardens. The high organic matter content variability in Lisbon and Nantes is probably related to specific gardening practice and varied by addition of organic amendment. In Lisbon, for example, large amounts of organic materials from a big variety of sources and with different decomposition rates are applied (Cameira et al. 2014). Neutral to high $\mathrm{pH}$ and $\mathrm{OM}$ content favor trace element adsorption and/or precipitation and low bioavailability and leaching capacities. The significant $\mathrm{CaCO}_{3}$ concentrations found in some Lisbon allotments will produce a similar effect, especially on lead and zinc retention. Recently, Brown et al. (2016) concluded that common management practices in gardens, e.g., organic matter and amendments supply, assure minimal potential for exposure, then minimizing the risk for gardeners.

Considering all the data of variability at the city scale, some hypothesis about sources of some of the trace elements may be drawn. The geogenic signatures seem to be important for lead and zinc in both cities and nickel in Lisbon. The carbonate content in soil could control the mobilities of $\mathrm{Pb}$ and $\mathrm{Zn}$ that should also have an anthropogenic origin considering the extreme values. In Nantes, the high values of cadmium concentrations and extreme values in some soils may be related to anthropogenic inputs.

Even if the city scale could not be considered as a relevant scale for soil management due to too numerous parameters to 
Table 2 Soil samples collected, sampling and metal content analysis methodology used for each city

\begin{tabular}{|c|c|c|c|c|}
\hline City & $\begin{array}{l}\text { No. of studied UAGs } \\
\text { No. of plots in each garden }\end{array}$ & No. of sampling points & Collection method & Method for metal content analysis \\
\hline Ayr & 1 & 8 & $\begin{array}{l}\text { Steel coring device, } 1 \text { composite sample } \\
\quad(5 \text { subsamples }(0-20 \mathrm{~cm})) \text { from } 8 \text { plots } \\
\text { W sampling pattern }\end{array}$ & ICP-OES/MS \\
\hline Greenock & 1 & 11 & $\begin{array}{l}\text { Steel coring device, } 1 \text { composite sample } \\
\quad(5 \text { subsamples }(0-20 \mathrm{~cm})) \text { from } 11 \text { plots } \\
\text { W sampling pattern }\end{array}$ & ICP-OES/MS \\
\hline Lisbon & 10 to more than -100 & 18 & $\begin{array}{l}\text { Hand spade, } 1 \text { composite sample ( } 3 \\
\text { subsamples }(0-5 \mathrm{~cm})) \text { from } 18 \text { plots } \\
(3 \text { plots per UAG) } \\
\text { Random sampling pattern }\end{array}$ & PXRF in lab \\
\hline \multirow[t]{5}{*}{ Nantes } & 6 & 30 & $\begin{array}{l}\text { Steel coring device, } 1 \text { composite sample } \\
\quad(20 \text { subsamples }(0-20 \mathrm{~cm})) \text { from } 30 \text { plots } \\
(5 \text { plots per UAG) }\end{array}$ & ICP-OES/MS \\
\hline & 39 up to- 95 & & Random sampling pattern & PXRF in lab \\
\hline & & 263 & $\begin{array}{l}\text { Steel coring device, } 1 \text { composite sample } \\
\quad(1 \text { to } 3 \text { subsamples }(0-20 \mathrm{~cm}))\end{array}$ & In situ PXRF \\
\hline & & $\begin{array}{l}\text { ( } 29 \text { to } 100 \% \text { of the } \\
\text { plots in the } 6 \text { UAGs) }\end{array}$ & Random sampling pattern & \\
\hline & & 32 & $\begin{array}{l}\text { Steel coring device, } 4 \text { plots divided in } \\
8 \text { small areas }\left(6 \mathrm{~m}^{2}\right) \text { each } \\
1 \text { composite sample }(5 \text { subsamples } \\
(0-20 \mathrm{~cm}), 4 \text { in the corner, } 1 \text { in } \\
\text { the middle of each area })\end{array}$ & In situ PXRF \\
\hline
\end{tabular}

explain the variability of trace element distribution, the cityscale approach is useful to gain range of values and detect potential zones of trace element hot spots, which origin should be determined at the garden scale.

\subsection{Considering local environmental conditions} and histories as factors of trace element variability at garden scale — case of Scottish, Portuguese, and French gardens

Datasets are available to carry out inter-allotment comparisons within the four cities (Ayr, Greenock, Lisbon, Nantes), focusing on the specificities of each garden to explain the variability. Trace element concentrations $(\mathrm{Cd}, \mathrm{Cu}, \mathrm{Cr}, \mathrm{Ni}$, $\mathrm{Pb}, \mathrm{Zn}$ ) are shown graphically in Fig. 3. Data for soil properties within garden sites are presented in Table 5 and are considered as local environmental parameters.
The $\mathrm{pH}$ values (mean value, $\mathrm{RSD}$ ) are very similar to those observed at city scale. The data are very homogeneous at garden scale and to a less extent between gardens. On the contrary, $\mathrm{CaCO}_{3}$ and organic matter contents are different from one garden to another. The RSD for OM is higher in the two gardens of Nantes than in Lisbon gardens. These results may reflect various gardening practices between UAG users. The practice in Lisbon seems to be more homogeneous at garden scale and reflects variation in attitudes found in allotment garden users (Voigt et al. 2015). Metals such as Fe and Mn are also considered as components of reactive solid phases. They are present with extreme values in Greenock and Lisbon in relation with local geology. The Fe and Mn values are close in Ayr and Nantes garden soils. A higher deviation is found for $\mathrm{Cu}, \mathrm{Pb}$, and $\mathrm{Zn}$ in relation with extreme values of $\mathrm{Fe}$ and $\mathrm{Mn}$ measured in samples of Wellington, CRIL, or Crapaudine for example.
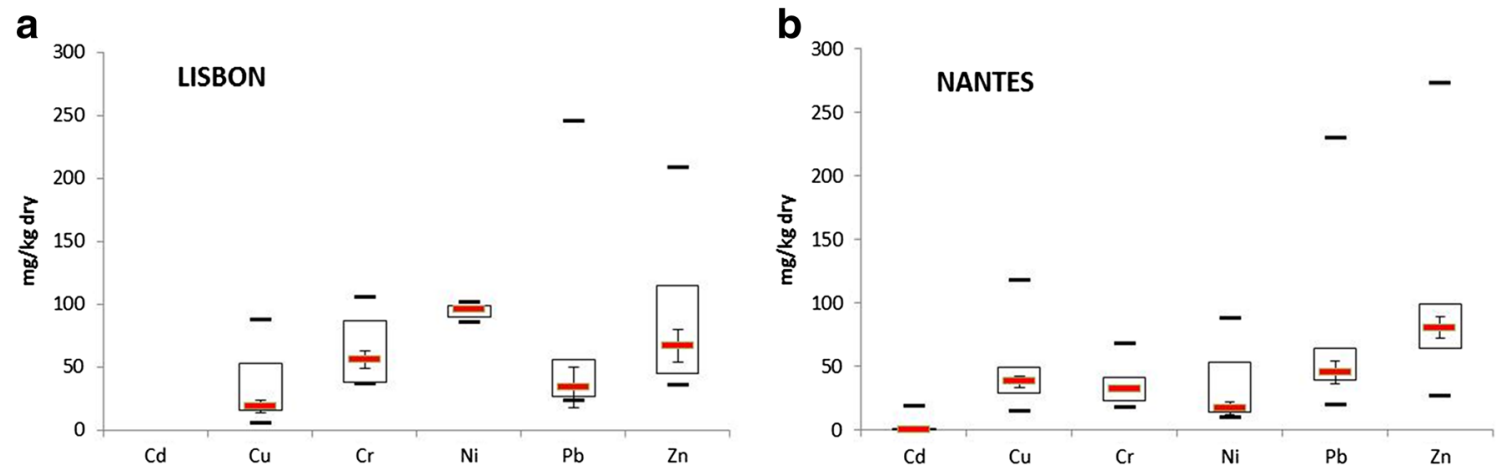

Fig. 2 Box plots of trace element concentrations $(\mathrm{Cd}, \mathrm{Cu}, \mathrm{Cr}, \mathrm{Ni}, \mathrm{Pb}, \mathrm{Zn})$ in urban allotment garden surface soils of a Lisbon (Portugal) and $\mathbf{b} \mathrm{Nantes}$ (France) (median value, percentiles ( 25 and $75 \%$ ), minimum and maximum values, standard error) 
Table 3 Selection of basic soil properties at city scale

\begin{tabular}{lrrrl}
\hline & $\mathrm{pH}_{\mathrm{H} 2 \mathrm{O}}$ & $\begin{array}{l}\mathrm{CaCO}_{3} \\
\left(\mathrm{~g} \mathrm{~kg}^{-1}\right)\end{array}$ & $\begin{array}{l}\text { Organic } \\
\text { matter } \\
\left(\mathrm{g} \mathrm{kg}^{-1}\right)\end{array}$ & Texture \\
\hline Lisbon $(n=18)$ & & & & Sandy loam \\
$\quad$ Mean & 7.9 & 40.9 & 28.0 & \\
RSD (\%) & 4.4 & 86.4 & 45.6 & \\
SE & 0.1 & 8.6 & 3.1 & \\
Minimum & 7.1 & 9.2 & 11.2 & \\
Maximum & 8.3 & 115.8 & 46.5 & \\
Nantes $(n=14)$ & & & & Sandy loam to silty sand \\
Mean & 7.2 & 4.2 & 34.3 & \\
RSD (\%) & 6.3 & 142 & 39 & \\
SE & 0.1 & 1.6 & 3.7 & \\
Minimum & 6.2 & 0.0 & 18.8 & \\
Maximum & 7.8 & 19.8 & 76.3 & \\
\hline
\end{tabular}

$R S D(\%)$ relative standard deviation, $S E$ standard error

A high variability of trace element concentrations in gardens of Lisbon and Nantes is observed that should be influenced mainly by the nature and origin of trace element, the main properties of soil, and the history of sites. The ranges of trace element concentrations are close in the gardens of Ayr, Lisbon, and Nantes (Fig. 5). But in Greenock, the concentrations are 10 times higher, except for $\mathrm{Cd}$ and $\mathrm{Cr}$.
The two cities in Scotland reflect different degrees of industrialization and subsequently intensity of garden use over time. The location in Greenock (Wellington) was historically more urbanized and subject to wider range and more prolonged urbanization. The Ayr site (Craigie) is on the edge of a city in a rural environment and less disturbed by industrial activity. Soil properties are less variable, and while the strong urban elements, e.g., $\mathrm{Pb}$ and $\mathrm{Zn}$, are enriched, the level and variability are much lower than in Wellington (see Electronic supplementary material for lead mapping (Fig. S1)). Data shows low variation for some of the classic background elements in Scottish sites $(\mathrm{Pb}, \mathrm{Zn})$, and to a less extent, $\mathrm{Cu}$ and $\mathrm{Ni}$ have a higher variability with the variability of $\mathrm{Pb}$ extremely high in comparison.

The garden locations in Lisbon reflect different geological backgrounds and land use. Trace elements such as $\mathrm{Cr}$ (only present in CRIL and Granja Nova), $\mathrm{Cu}, \mathrm{Ni}$, and $\mathrm{Zn}$ can derive from the chemical composition of the volcanic parent rocks (Fig. 1b). The highest values of Fe and $\mathrm{Mn}$ in Lisbon UAGs are present in soils with volcanic origin. This is the case of CRIL and, to a lower extent, both Granja's. Another possible origin for the highest concentrations of trace elements in CRIL may also be related to its location next to a main circular (Lisbon Regional Internal Circular), but more soil data information should be gathered to confirm this.

Table 4 Selection of major elements and trace element content (city scale)

\begin{tabular}{|c|c|c|c|c|c|c|c|c|}
\hline & \multirow[t]{2}{*}{$\mathrm{Fe}\left(\mathrm{g} \mathrm{kg}^{-1}\right)$} & \multirow[t]{2}{*}{$\operatorname{Mn}\left(\mathrm{g} \mathrm{kg}^{-1}\right)$} & \multicolumn{6}{|l|}{$\mathrm{mg} \mathrm{kg}^{-1}$} \\
\hline & & & $\mathrm{Cd}$ & $\mathrm{Cu}$ & $\mathrm{Cr}$ & $\mathrm{Ni}$ & $\mathrm{Pb}$ & $\mathrm{Zn}$ \\
\hline \multicolumn{9}{|l|}{ Lisbon $(n=18)$} \\
\hline Mean & 28.3 & 394.1 & $<\mathrm{LOD}$ & 31.5 & 63.6 & 93.7 & 66.1 & 86.0 \\
\hline RSD (\%) & 96 & 136 & & 71 & 44 & 7.5 & 102 & 60 \\
\hline $\mathrm{SE}$ & 6.6 & 130 & & 5.4 & 6.8 & 1.7 & 16.4 & 12.5 \\
\hline Minimum & 10.1 & 10.2 & $<\mathrm{LOD}$ & 4.5 & 35.4 & 84.3 & 22.8 & 34.8 \\
\hline Maximum & 94.3 & 1645.9 & $<\mathrm{LOD}$ & 87.1 & 105.0 & 101.1 & 244.5 & 207.9 \\
\hline \multicolumn{9}{|l|}{ Nantes $(n=29)$} \\
\hline Mean & 11.5 & 407.3 & 2.1 & 42.3 & 33.3 & 30.1 & 60.6 & 86.4 \\
\hline RSD (\%) & 56 & 31 & 250 & 56 & 38 & 83 & 73 & 52 \\
\hline $\mathrm{SE}$ & 1.3 & 27.7 & 1.0 & 4.7 & 2.6 & 4.9 & 9.2 & 8.9 \\
\hline Minimum & 1.6 & 264.0 & 0.1 & 13.3 & 17.1 & 8.4 & 18.6 & 26.1 \\
\hline Maximum & 28.0 & 835.2 & 17.7 & 117.0 & 66.8 & 87.0 & 228.7 & 272.0 \\
\hline Igneous rocks & & & $0.13^{\mathrm{a}}-0.10^{\mathrm{b}}$ & $90^{\mathrm{a}, \mathrm{b}}$ & $200^{\mathrm{a}}-168^{\mathrm{b}}$ & $150^{\mathrm{a}}-134^{\mathrm{b}}$ & $3^{\mathrm{a}}-3.5^{\mathrm{b}}$ & $100^{\mathrm{a}, \mathrm{b}}$ \\
\hline Sedimentary rocks ${ }^{\mathrm{a}}$ & & & $0.028^{\mathrm{c}}-0.05^{\mathrm{d}}$ & $5.5^{\mathrm{c}}-30^{\mathrm{d}}$ & $11^{\mathrm{c}}-35^{\mathrm{d}}$ & $7^{\mathrm{c}}-9^{\mathrm{d}}$ & $5.7^{1}-10^{\mathrm{d}}$ & $20^{1}-30^{\mathrm{d}}$ \\
\hline
\end{tabular}

$R S D(\%)$ relative standard deviation, $S E$ standard error

${ }^{a}$ Average concentration depending on the type of parent rock (igneous or sedimentary rocks). Data from Alloway (1990)

${ }^{\mathrm{b}}$ Average concentration depending on the type of parent rock (igneous or sedimentary rocks). Data from Merian (1991)

${ }^{\mathrm{c}}$ Average concentration depending on the type of parent rock (sedimentary rocks), limestone

${ }^{\mathrm{d}}$ Average concentration depending on the type of parent rock (sedimentary rocks), sandstone 

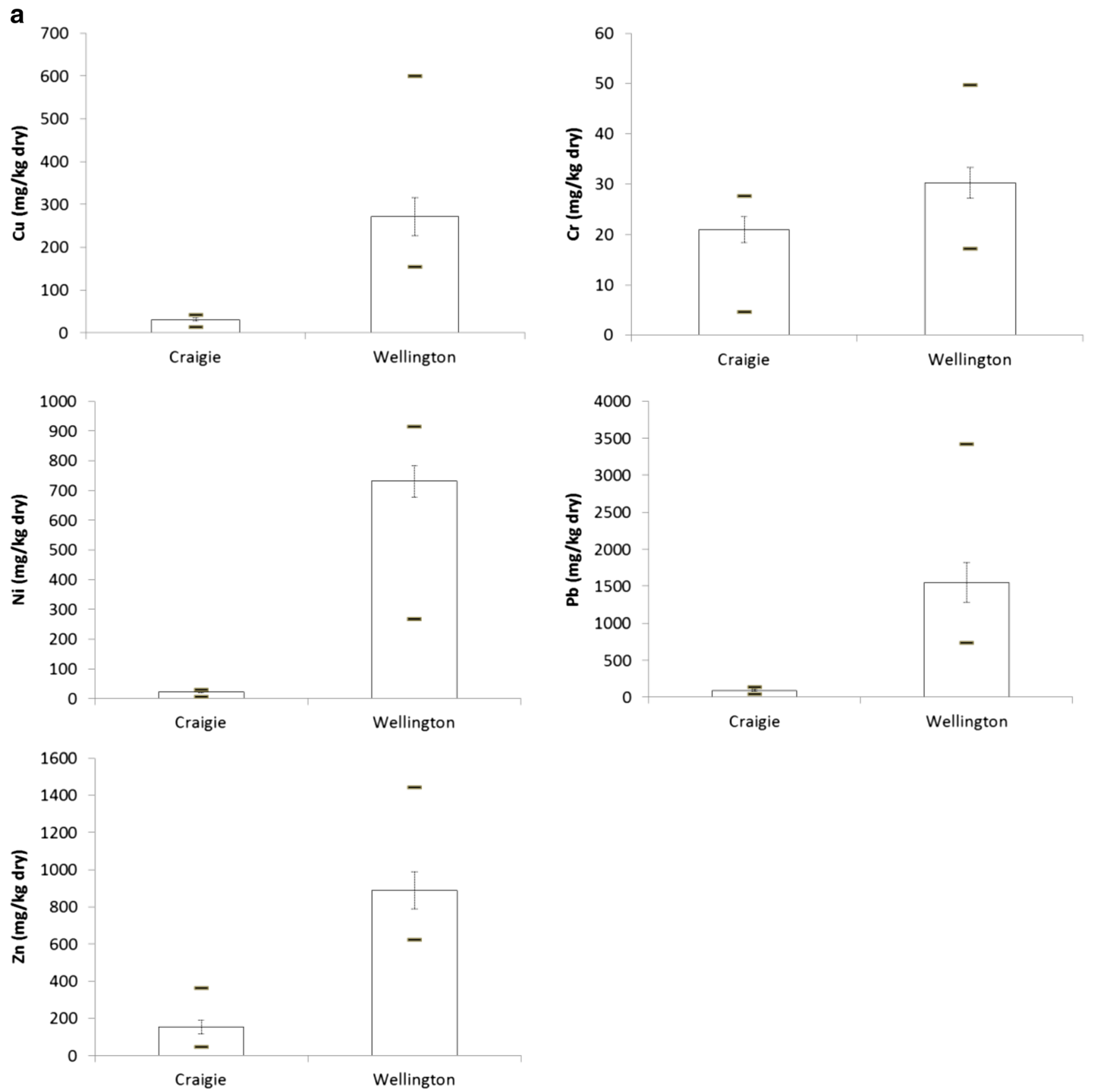

Fig. 3 Metal content within garden sites in a Ayr (Craigie $n=8)$ and Greenock (Wellington $n=11$ ), $\mathbf{b}$ Lisbon $(n=3$ per garden site or all values are under limit of quantification), and $\mathbf{c}$ Nantes ( $n=5$ except for garden

There is no clear effect of higher soil trace element content due to the proximity of LNEC and CHPL UAGs to Lisbon airport. In brief, Lisbon UAG soils contain several elements whose concentration is above the threshold value (Ontario or Dutch standards), $\mathrm{Pb}, \mathrm{Cr}$, $\mathrm{Ni}$, and Zn, especially for soil samples from CRIL and Quinta da Granja gardens. In other areas, there was only one case of elevated $\mathrm{Pb}$ in one of LNEC samples, but this was not confirmed in further analysis. Lisbon UAG sites where some $\mathrm{Cu}, \mathrm{Cr}$ and $\mathrm{Ni}$ values are under limit of quantification) (mean value, standard error, minimum, maximum)

heterogeneity in soil trace element concentrations was mainly a result of the background geochemistry, with the highest values belonging to the volcanic origin soils. Exposure to road and traffic can also justify some of the soil trace element concentrations obtained. Moreover, there is no clear effect from influence of the airport in the two allotments close to it. Samples of dry atmospheric deposition carried out in the same six UAGs have shown low contributions of trace elements and 

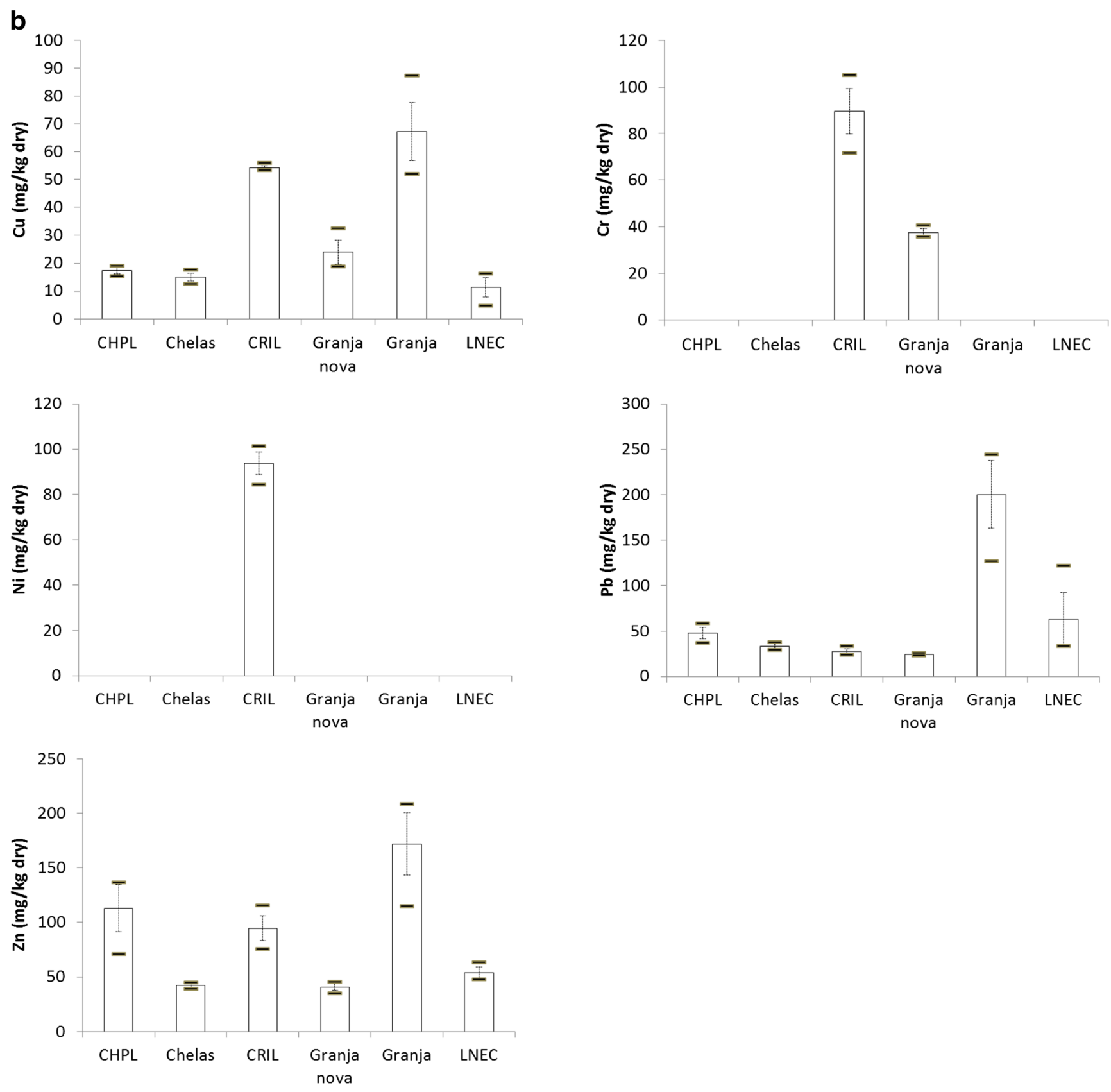

Fig. 3 (continued)

hydrocarbons, but its cumulative effect should be further studied (Leitão et al. 2016).

Among the trace elements studied, lead is the only one that could be above the natural background in the gardens of Nantes. Arsenic is also a main element of the geochemical background in Nantes region (Jean-Soro et al. 2015). It was often found in association with lead within alterites of micaschists. Past land use of garden soils was deduced from historical data and aerial pictures, farming (Eglantiers, Chaupières), market gardening (Contrie, Crapaudine), and past industrial activities (Batignolles). The evolution of the land use was very useful to discriminate between lead sources. For example, in Chaupières garden, a third of the plots were covered by As- and $\mathrm{Pb}$-rich alterites of micaschists bought on site during the construction of the ring road of Nantes. The natural origin of the contamination was assessed, as those of Eglantiers. The use of plant-protection products or material from more intensive market gardening remains the likely explanation for the contamination in Contrie and Crapaudine gardens. The soil of Batignolles garden exhibits typical 

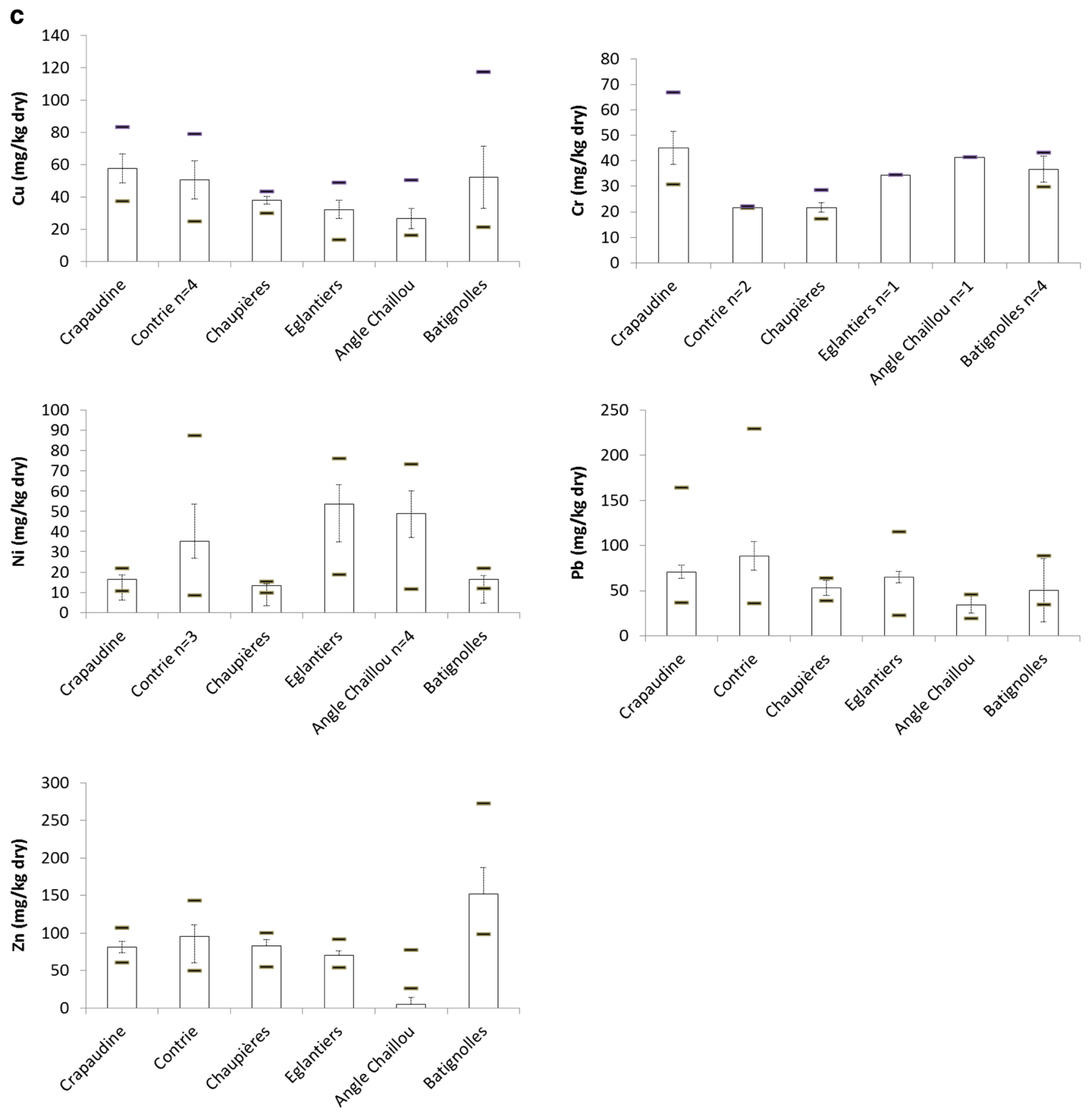

Fig. 3 (continued)

aspects of technosols (artifacts, color, and superposition of various soil layers). Some high values of $\mathrm{Cu}$ observed could be attributed to cultivation practices (e.g., application of $\mathrm{CuSO}_{4}$ ). In brief, the results highlight the wide variation in contamination of soils (e.g., background geochemistry, contaminated backfill materials, cultivation practices). No influence of traffic was detected on the study sites.

The sources of contaminant input should be discriminated during the diagnostic stage of the soil quality. In most situations, the historical and environmental study of the site has been helpful in understanding the nature and distribution of contamination and in detecting hot spots or hot zones.

\subsection{Using PXRF screening as a useful tool for soil management - case of Nantes UAGs}

The results of the previous section are based on sampling and chemical analyses of 3 to 11 soil samples per garden. 
Table 5 Soil properties within garden sites in Scotland (S), Lisbon (L), and Nantes $(\mathrm{N})$

\begin{tabular}{|c|c|c|c|c|c|c|}
\hline & $\begin{array}{l}\mathrm{pH}- \\
\mathrm{H} 2 \mathrm{O}\end{array}$ & $\begin{array}{l}\mathrm{CaCO}_{3} \\
\left(\mathrm{~g} \mathrm{~kg}^{-1}\right)\end{array}$ & $\begin{array}{l}\text { Organic } \\
\text { matter } \\
\left(\mathrm{g} \mathrm{kg}^{-1}\right)\end{array}$ & $\begin{array}{l}\mathrm{Fe} \\
\left(\mathrm{g} \mathrm{kg}^{-1}\right)\end{array}$ & $\begin{array}{l}\mathrm{Mn} \\
\left(\mathrm{mg} \mathrm{kg}^{-1}\right)\end{array}$ & Texture \\
\hline \multicolumn{7}{|c|}{ Craigie (S-Ayr; $n=8)$} \\
\hline Mean & 6.3 & nd & 17.6 & 21.8 & 704.5 & Sandy loam \\
\hline $\operatorname{RSD}(\%)$ & 0.5 & nd & 1.1 & 44 & 33 & \\
\hline Minimum & 5.7 & nd & 15.5 & 4.6 & 403.9 & \\
\hline Maximum & 7.2 & nd & 18.7 & 33.2 & 998.3 & \\
\hline \multicolumn{7}{|c|}{ Wellington (S-Greenock; $n=11$ ) } \\
\hline Mean & 6.4 & nd & 17.8 & 47.1 & 2,774 & Sandy loam \\
\hline RSD (\%) & 0.4 & nd & 1.8 & 33 & 241 & \\
\hline Minimum & 5.9 & nd & 15.9 & 23.0 & 353.8 & \\
\hline Maximum & 7.5 & nd & 21.2 & 80.4 & 22,960 & \\
\hline \multicolumn{7}{|c|}{ CHPL $(\mathrm{L} ; n=3)$} \\
\hline Mean & 7.2 & 10.8 & 45.8 & & & Sandy loam \\
\hline $\operatorname{RSD}(\%)$ & 0.1 & 2.2 & 0.9 & & & \\
\hline Minimum & 7.1 & 9.2 & 44.8 & & & \\
\hline Maximum & 7.3 & 13.3 & 46.5 & & & \\
\hline \multicolumn{7}{|c|}{ Chelas (L; $n=3$ ) } \\
\hline Mean & 8.1 & 23.9 & 12.3 & & & Sandy loam \\
\hline $\operatorname{RSD}(\%)$ & 0.1 & 0.5 & 1.2 & & & \\
\hline Minimum & 8.0 & 23.3 & 11.2 & & & \\
\hline Maximum & 8.1 & 24.2 & 13.6 & & & \\
\hline \multicolumn{7}{|c|}{ CRIL $(\mathrm{L} ; n=3)$} \\
\hline Mean & 8.2 & 107.5 & 17.5 & & & Sandy loam \\
\hline $\operatorname{RSD}(\%)$ & 0.1 & 7.6 & 0.4 & & & \\
\hline Minimum & 8.1 & 100.8 & 17.1 & & & \\
\hline \multirow{2}{*}{\multicolumn{7}{|c|}{ Granja nova $(\mathrm{L} ; n=3)$}} \\
\hline & & & & & & \\
\hline Mean & 8.3 & 17.5 & 28.8 & & & Sandy loam \\
\hline $\operatorname{RSD}(\%)$ & 0.1 & 0.8 & 1.3 & & & \\
\hline Minimum & 8.2 & 16.7 & 27.2 & & & \\
\hline Maximum & 8.3 & 18.3 & 29.7 & & & \\
\hline \multicolumn{7}{|c|}{ Granja (L; $n=3)$} \\
\hline Mean & 7.9 & 44.7 & 43.3 & & & Sandy loam \\
\hline RSD (\%) & 0.1 & 3.2 & 2.3 & & & \\
\hline Minimum & 7.8 & 42.5 & 41.0 & & & \\
\hline Maximum & 8.0 & 48.3 & 45.7 & & & \\
\hline \multicolumn{7}{|c|}{ LNEC $(\mathrm{L} ; n=3)$} \\
\hline Mean & 8.0 & & 20.1 & & & Sandy loam \\
\hline $\operatorname{RSD}(\%)$ & 0.0 & & 0.0 & & & \\
\hline Minimum & 8.0 & & 20.1 & & & \\
\hline Maximum & 8.0 & & 20.1 & & & \\
\hline \multicolumn{7}{|c|}{ Crapaudine $(\mathrm{N} ; n=5)$} \\
\hline Mean & 6.8 & 0.3 & 32.8 & & & Sandy loam \\
\hline $\operatorname{RSD}(\%)$ & 0.3 & 0.8 & 10.1 & & & to silty \\
\hline Minimum & 6.2 & 0.0 & 18.8 & & & sand \\
\hline Maximum & 7.0 & 1.7 & 46.8 & & & \\
\hline \multicolumn{7}{|c|}{ Batignolles $(\mathrm{N} ; n=4)$} \\
\hline Mean & 7.4 & 4.3 & 42.5 & & & Sandy loam \\
\hline $\operatorname{RSD}(\%)$ & 0.3 & 4.0 & 22.7 & & & \\
\hline Minimum & 7.0 & 0.0 & 29.0 & & & \\
\hline Maximum & 7.7 & 9.4 & 76.3 & & & \\
\hline
\end{tabular}

nd not determined, $R S D(\%)$ relative standard deviation

In case of contamination, when there is up to 100 plots or more in a garden, an efficient soil management requires a diagnostic over a surface as large as possible. The PXRF screening was tested in few gardens of Nantes at garden scale and plot scale.

Figures 4 and 5 illustrate the variability of two parameters ( $\mathrm{pH}$ and $\mathrm{Pb}$ concentration of soil (PXRF screening)) at very small scale (plot scale) and small scale in two gardens of Nantes. Classes of anomalies defined in Le Guern et al. (2013) were used for mapping the lead concentration in garden, no anomaly $[\mathrm{Pb}]<60 \mathrm{mg} \mathrm{kg}^{-1}$, moderate anomaly $60<[\mathrm{Pb}]<100 \mathrm{mg} \mathrm{kg}^{-1}$, and high anomaly $100<[\mathrm{Pb}]<500 \mathrm{mg} \mathrm{kg}^{-1}$. In the Crapaudine garden, only a

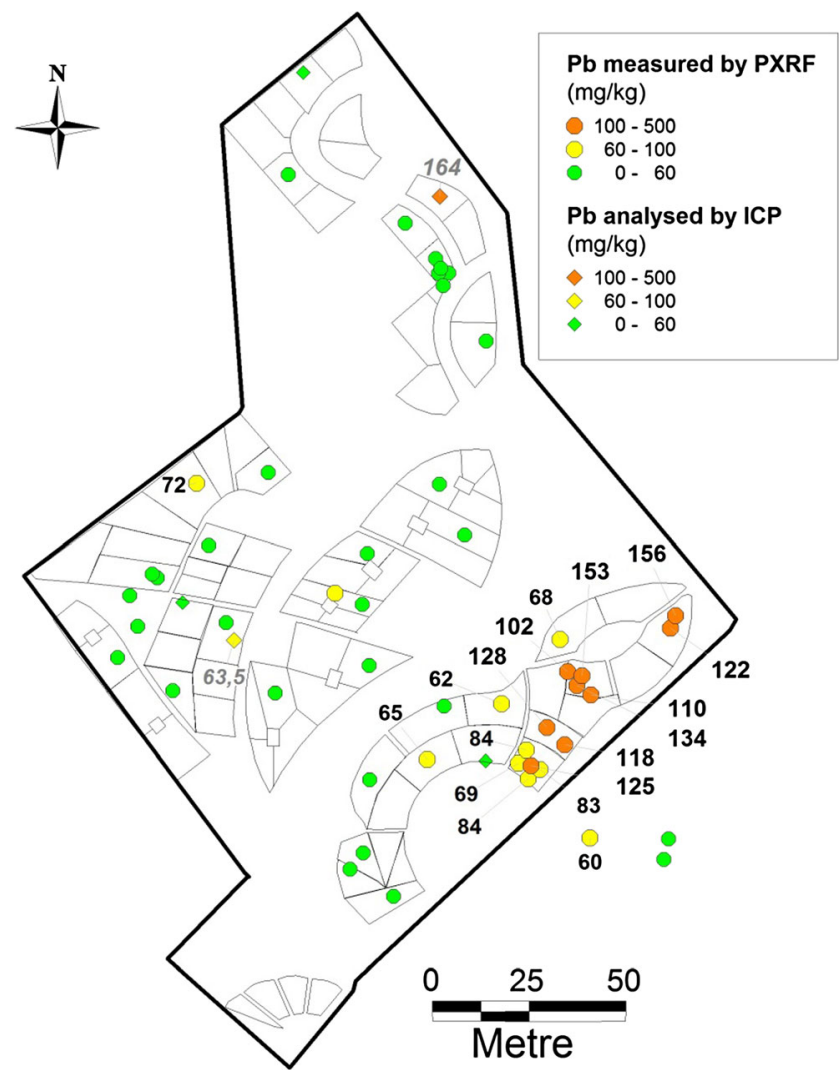

Fig. 4 Map of lead concentration $\left(\mathrm{mg} \mathrm{kg}^{-1}\right)$ in the Crapaudine garden (Nantes) - dataset $\mathrm{Pb}$ measured by PXRF per plot and $\mathrm{Pb}$ measured by ICP per plot

very small portion of the total area exceeds $100 \mathrm{mg} \mathrm{kg}^{-1}$ soil lead content (high anomaly level), where gardening would entail unacceptable level of lead in specific vegetables (CEN 1881/2006). In the Eglantiers garden, the same high-precision assessment leads to the conclusions that only one half of the garden surface have to be considered in a remedial management plan. The Eglantiers garden could be divided in two parts, with respect to $\mathrm{Pb}$ concentrations (Fig. 5a). The highest $\mathrm{Pb}$ concentrations ("high-anomaly" class) were measured in the western and central side part of the garden.

At the plot scale, a high variability in $\mathrm{pH}$ and $\mathrm{Pb}$ values (Fig. 5b) was highlighted between small zones of $6 \mathrm{~m}^{2}$ $\left(5.75<\mathrm{pH}<7.63 ; 97 \mathrm{mg} \mathrm{kg}^{-1}<\mathrm{Pb}<314 \mathrm{mg} \mathrm{kg}^{-1}\right)$. In term of soil management, this information can help to improve gardening practice and target more effective soil remediation options. Area with low $\mathrm{pH}$ could be amended with organic matter and lime. Local authorities could also define a list of authorized vegetables that do not accumulate $\mathrm{Pb}$. Additional measurements on lead content in various vegetables in the garden highlighted that not only the variability of $\mathrm{Pb}$ concentration in soil but also the vegetable species could impact the quality of vegetable (see Electronic supplementary material (Fig. S2)). It may be postulated that interactions between the constitutive ability 
Fig. 5 Map of a lead concentration in the Eglantiers garden (Nantes) with location of very small scale investigation zone (modified from Jean-Soro et al. (2015)), b pH value ( $\mathrm{pH}=5.75$ (yellow) to $\mathrm{pH} 7.63$ (blue)), and $\mathbf{c}$ lead concentration (97 mg/kg (blue) to $317 \mathrm{mg} / \mathrm{kg}$ (red)) within four plots a

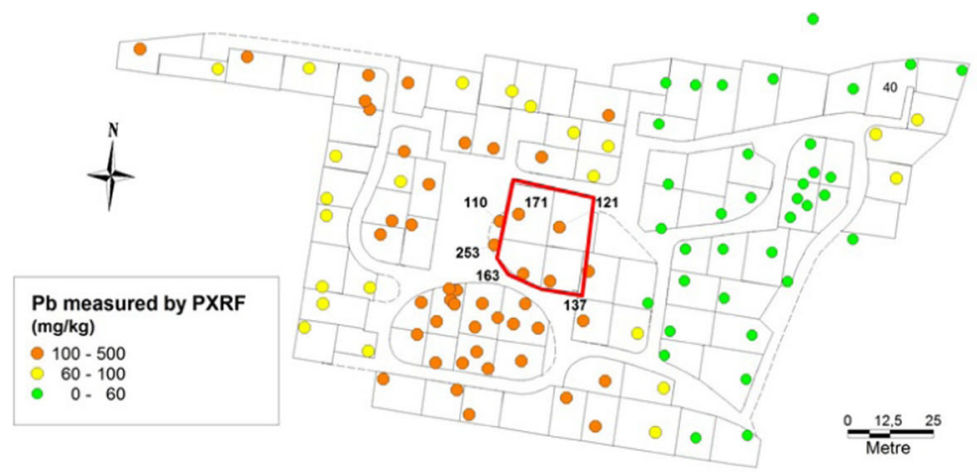

b

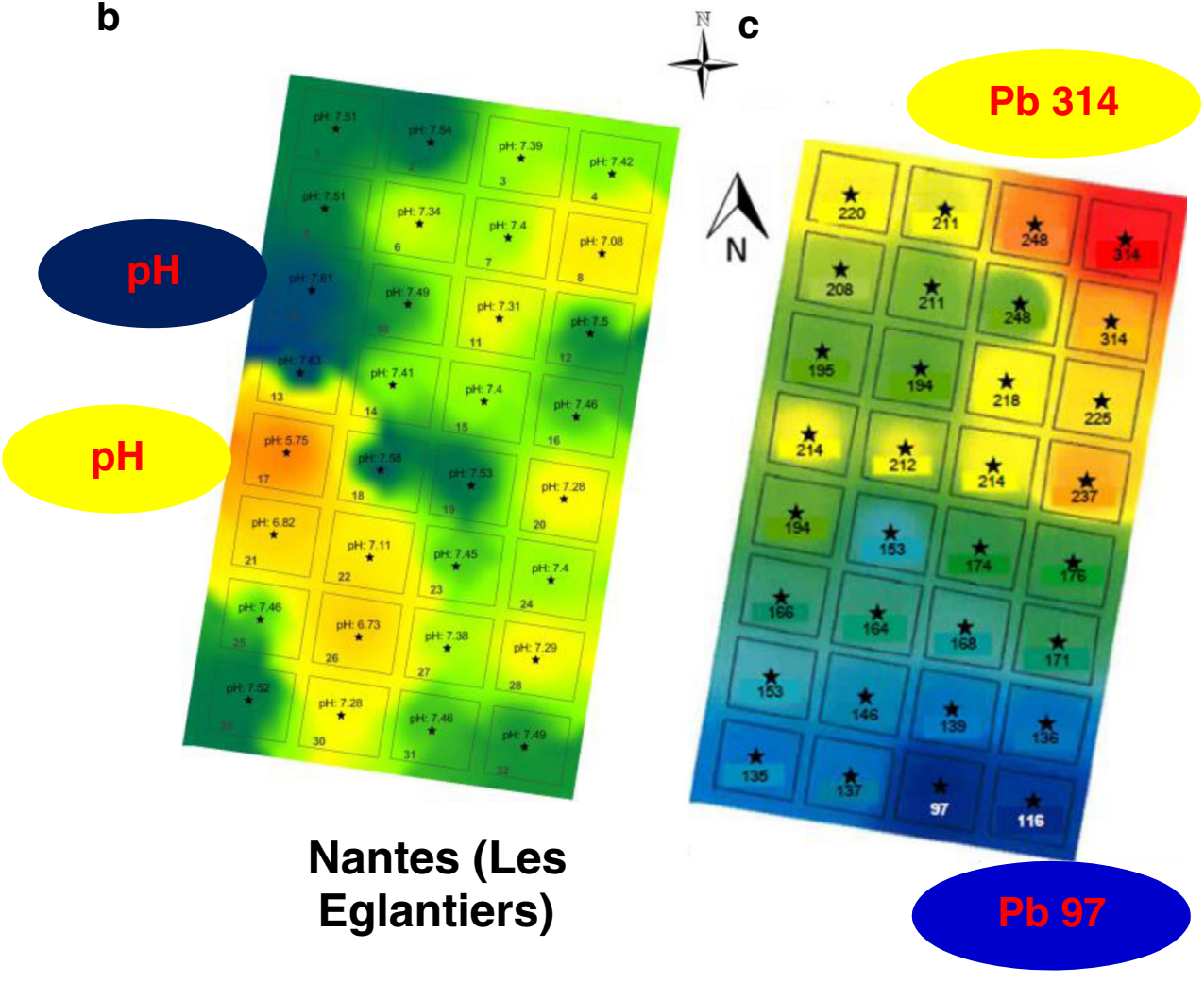

of vegetable to accumulate more or less $\mathrm{Pb}$ and the variations of $\mathrm{Pb}$ bioavailability ruled by several factors $(\mathrm{pH}$, $\% \mathrm{OM}, \%$ clay, etc.) explain low correlation between concentrations in soils and vegetables.

The spatial distribution of trace elements such as $\mathrm{Pb}$ and $\mathrm{Zn}$ was very heterogeneous within each UAG in Nantes. The portable X-ray fluorescence method in situ investigation with spectrometry was proposed to local authorities (in Nantes) to produce trace elements maps of UAGs, when contamination of vegetables was detected. As suggested by Bugdalski et al. (2014), the PXRF method and mapping are proved helpful in delineating areas of concern. This method was cost-effective by comparison to detailed analysis of metal bioavailability as suggested by Clarke et al. (2015). It seems a reasonable strategy to accommodate the heterogeneity of UAG soil quality and to keep restriction on cultivation on relevant plots.

\section{Conclusions}

Spatial variability of trace element distribution in urban garden soils of four European cities was assessed from a city, garden, and plot scale. Low differences in the basic soil properties are identified - homogeneity is good within the city and only slightly different between cities, as it might be expected from the geological context. The trace element distribution shows much more variability between background contributions and elements strongly enhanced by urbanization through industrial activity or other sources 
of pollution such as traffic emissions. The evaluation of soil quality is initiated based on different history of land use and contributions from parent materials. Enhancement of metal and metalloid levels in urban soils is usually considered to have an anthropogenic origin, due to intense human activities, but in this study, the geogenic origin of inputs was also relevant for trace element anomalies in several gardens, confirming variability of inputs seen in other urban soil contexts (Rodrigues et al. 2009).

Some trace elements, such as $\mathrm{Pb}, \mathrm{Cu}$, or $\mathrm{Zn}$, exhibit high variability at small scale (garden scale) and very small scale in many of the gardens studied. As previously suggested, the development of accurate sampling methodology and/or in situ measurement could be promoted as a useful tool for issues of spatial variability and decisions for risk assessment and soil management. The cost of intensive small-scale sampling is usually prohibitive for evaluation on a plot-to-plot basis. The portable X-ray fluorescence screening method proved to be an efficient solution to detect or delineate hot spots. Trace element maps could be effectively used to discriminate zones which might be subject to restriction on cultivation.

Acknowledgments The studies carried out in the three countries were supported by the COST Action TU1201 "Urban Allotment Gardens", the municipalities of Lisbon (Portugal) and Nantes (France), and the French National Research Agency (JASSUR project ANR-12-VBDU-0011). The authors wish to thank Alain Rakoto and Laurent Lebouc (technical staff of the LSE and IFSTTAR, respectively) and Dr. Jérôme Cortet.

\section{References}

AFNOR (2005) NF ISO 10390 - Qualité des sols - Détermination du pH. Association Française de NORmalisation

Ander EL, Johnson CC, Cave MR, Palumbo-Roe B, Nathanail CP, Lark RM (2013) Methodology for the determination of normal background concentrations of contaminants in English soils. Sci Total Environ 454-455:604-618

Alloway BJ (1990) Heavy metals in soils. Blackie (Ed), ISBN: 0470215984, 9780470215982, $339 \mathrm{pp}$

Béchennec F (2007) Carte géologique harmonisée du département de Loire-Atlantique. Report BRGM/RP-55703-FR, pp 369

Béchet B, Carré F, Florentin L, Leyval C, Montanarella L, Morel JL, Raimbault G, Rodriguez F, Rossignol JP, Schwartz C (2009) Caractéristiques et fonctionnement des sols urbains. In: Cheverry et Gascuel (éd) Sous les pavés la terre, Omniscience, Montreuil, pp 45-74

Bian B, Zhou LJ, Li L, Lv L, Fan YM (2015) Risk assessment of heavy metals in air, water, vegetables, grains, and related soils irrigated with biogas slurry in Taihu Basin, China. Environ Sci Pollut Res Int 22: 7794-7807

Brown SL, Chaney RL, Hettiarachchi GM (2016) Lead in urban soils: a real or perceived concern for urban agriculture? J Environ Qual 45:26-36

Bugdalski L, Lemke LD, McElmurry SP (2014) Spatial variation of soil lead in an urban community garden: implication for risk-based sampling. Risk Anal 34(1):17-27

Cachada L, Lopes V, Hursthouse AS, Biasioli M, Grčman H, Otabbong E, Davidson CM, Duarte AC (2009) Distribution and trends of polychlorinated biphenyls in urban soils from five European cities. Environ Pollut 157:511-518
Cameira MR, Tedesco S, Leitão TE (2014) Water and nitrogen budgets under different production systems in Lisbon urban farming. Biosyst Eng 125:65-79

Clarke LW, Darrel Jenerette G, Bain DJ (2015) Urban legacies and soil management affect the concentration and speciation of trace metals in Los Angeles community garden soils. Environ Pollut 197:1-12

Douay F, Pelfrêne A, Planque J, Fourrier H, Richard A, Roussel H, Girondelot B (2013) Assessment of potential health risk for inhabitants living near a former lead smelter. Part 1: metal concentrations in soils, agricultural crops, and homegrown vegetables. Environ Monit Assess 185:3665-3680

Draper C, Freedman D (2010) Review and analysis of the benefits, purposes, and motivations associated with community gardening in the United States. J Community Pract 18:458-492

El Hamiani O, El Khalil H, Lounatea K, Sirguey C, Hafidi M, Bitton G, Schwartz C, Boularbah A (2010) Toxicity assessment of garden soils in the vicinity of mining areas in southern Morocco. J Hazard Mater 177: 755-761

Guitart D, Pickering C, Byrne J (2012) Past results and future directions in urban community gardens research. Urban For Urban Green $11: 364-373$

Hough RL, Breward N, Young SD, Crout NMJ, Tye AM, Moir AM, Thornton I (2004) Assessing potential risk of heavy metal exposure from consumption of home-produced vegetables by urban populations. Environ Health Persp 112:215-221

Hursthouse A, Tognarelli D, Tucker P, Marsan FA, Martini C, Madrid L, Madrid F, Diaz-Barrientos E (2004) Metal content of surface soils in parks and allotments from three European cities: initial pilot study results. Land Contam Reclam 12(3):189-197

Jean-Soro L, Le Guern C, Bechet B, Lebeau T, Ringeard MF (2015) Origin of trace elements in an urban garden in Nantes, France. J Soils Sediments 15(8):1802-1812

Joimel S, Cortet J, Jolivet CC, Saby NPA, Chenot ED, Branchu P, Consalès JN, Lefort C, Morel JL, Schwartz C (2016) Physico-chemical characteristics of topsoil for contrasted forest, agricultural, urban and industrial land uses in France. Sci Total Environ 545-546:40-47

Kabata-Pendias A (2001) Trace elements in soils and plants. CRC Press Taylor \& Francis Group, 505 pp

Karim Z, Qureshi BA, Mumtaz M, Qureshi S (2014) Heavy metal content in urban soils as an indicator of anthropogenic and natural influences on landscape of Karachi - a multivariate spatio-temporal analysis. Ecol Ind 42:20-31

Le Guern C, Baudouin V, Conil P, Courtais B avec la collaboration de Houel M, Coffinet A, Latourte C, Gourmelen F (2013) METOTRASS: méthodologie optimisée pour l'évaluation des teneurs en éléments trace $(\mathrm{As}, \mathrm{Pb}, \mathrm{Cu}, \mathrm{Zn}$ ) dans les sols en domaine de socle : test sur le département de la Loire-Atlantique - final report. ADEME. Angers, France Convention 0972C0030

Leitão TE (2007) Impact of road runoff in soil and groundwater. Portuguese and other European case studies. In: Water in Celtic Countries: Quantity, Quality and Climate Variability. Proceedings of the Fourth InterCeltic Colloquium on Hydrology and Management of Water Resources, Guimarães, Portugal. London: IAHS Red Books, IAHS Publication 310:338-347

Leitão TE, Henriques MJ, Cameira MR, Mourato M, Rodrigo I, Martins MLL, Costa HD, Pacheco JM (2016) Evaluation of soil, groundwater and vegetable quality in Lisbon urban allotment gardens. Identification of mitigation measures aimed at protecting public health (in Portuguese)

Li X, Liu L, Wang Y, Luo G, Chen X, Yang X, Hall MHP, Guo R, Wang H, Cui J, He X (2013) Heavy metal contamination of urban soil in an old industrial city (Shenyang) in northeast China. Geoderma 192:50-58

Liu X, Song Q, Tang Y, Li W, Xu J, Wu J, Wang F, Brookes PC (2013) Human health risk assessment of heavy metals in soil-vegetable system: a multi-medium analysis. Sci Total Environ 463-464:530-540 
Mc Bride M, Shayler HA, Spliethoff HM, Mitchell RG, Marquez-Bravo LG, Ferenz GS, Russell-Anelli JM, Casey L, Bachman S (2014) Concentrations of lead, cadmium and barium in urban garden-grown vegetables: the impact of soil variables. Environ Pollut 194:254-261

Merian E (1991) Metals and their compounds in the environment. Occurence, analysis and biological relevance. $\mathrm{VCH}$, Alemanha, ISBN 3-527-26521-X, $1438 \mathrm{p}$

Mitchell RG, Spliethoff HM, Ribaudo LN, Lopp DM, Shayler HA, Marquez-Bravo LG, Lambert VT, Ferenz GS, Russell-Anelli JM, Stone EB, McBride MB (2014) Lead (Pb) and other metals in New York City community garden soils: Factors influencing contaminant distributions. Environ Pollut 187:162-169

Moitinho de Almeida F (1986) Carta geológica do concelho de Lisboa, folha 1, 2, 3 e 4, escala 1:10000, Lisboa, serviços geológicos de Portugal

Morillo E, Romero AS, Maqueda C, Madrid L, Ajmone-Marsan F, Grcman H, Davidson CM, Hursthouse AS, Villaverde J (2007) Soil pollution by PAHs in urban soils: a comparison of three European cities. J Environ Monit 9(9):1001-1008

Nabulo G, Young SD, Black CR (2010) Assessing risk to human health from tropical leafy vegetables grown on contaminated urban soils. Sci Total Environ 408:5338-5351

Orecchio S (2010) Contamination from polycyclic aromatic hydrocarbons (PAHs) in the soil of a botanic garden localized next to a former manufacturing gas plant in Palermo (Italy). J Hazard Mater 180:590-601

Pais J, Moniz C, Cabral J, Cardoso J, Legoinha P, Machado S, Morais MA, Lourenço C, Ribeiro ML, Henriques P, Falé P (2006) Notícia Explicativa da Carta geológica 1:50.000, no. 34-D, Lisboa. Instituto Nacional de Engenharia, Tecnologia e Inovação. 74 pp

Papritz A, Reichard PU (2009) Modelling the risk of Pb and PAH intervention value exceedance in allotment soils by robust logistic regression. Environ Pollut 157:2019-2022

Rodrigues S, Urquhart G, Hossack I, Pereira ME, Duarte AC, Davidson C, Hursthouse A, Tucker R, Roberston D (2009) The influence of anthropogenic and natural geochemical factors on urban soil quality variability: a comparison between Glasgow, UK and Aveiro, Portugal. Environ Chem Lett 7:141-148

Schwartz C et al (2013) Jardins potagers : terres inconnues?, EDP Sciences, Collection « ADEME », ISBN : 978-2-7598-0723-9, 176 p

Schwarz K, Pickett STA, Lathrop RG, Weathers KC, Pouyat RV, Cadenasso ML (2012) The effects of the urban built environment on the spatial distribution of lead in residential soils. Environ Pollut 163:32-39

Singh S, Zacharias M, Kalpana S, Mishra S (2012) Heavy metals accumulation and distribution pattern in different vegetable crops. J Environ Chem Ecotoxicol 4:75-81

Szolnoki Z, Farsang A, Puskas I (2013) Cumulative impacts of human activities on urban garden soils: origin and accumulation of metals. Environ Pollut 177:106-115

Ters M, Barthélémy B, Marchand J, Richard R, Weecksteen G, Forestier FH, Lasnier B (1969) Carte géologique de la France/geological map of France (1/50000), feuille Nantes (481) —edited by BRGM, Orléans (France)

Voigt A, Latkowska MJ, Poniży L, Mizgajski A, Breuste J, Hursthouse A, Külvik M, Leitao T, Haas K, Artmann M, Rutecka A, Agboola A, Olonen A, Costa H (2015) Environmental behaviour of urban allotment gardeners In Europe Peer Reviewed Proceedings ECLAS 2015 Conference: Landscapes In Flux, pp78-82; ISBN: 978-9949-536-97-9

Webster R (2001) Statistics to support soil research and their presentation. Eur J Soil Sci 52:331-340

Yesilonis I, Pouyat R, Neerchal NK (2008) Spatial distribution of metals in soils in Baltimore, Maryland: role of native parent material, proximity to major roads, housing age and screening guidelines. Environ Pollut 156(3):723-731

Zahran S, Mielke HW, McElmurry SP, Filippelli GM, Laidlaw MAS, Taylor MP (2013) Determining the relative importance of soil sample locations to predict risk of child lead exposure Environ Int 60:7-14 